Красинский Владислав

Вячеславович, кандидат юридических наук

Источник опубликования: Красинский В.В. Теоретико-правовые аспекты легитимации избирательного процесса в интересах защиты конституционного строя // Современное право. 2010. № 3. С. 9-13; www.krasinskiy.ru

\title{
ТЕОРЕТИКО-ПРАВОВЫЕ АСПЕКТЫ ЛЕГИТИМАЦИИ ИЗБИРАТЕЛЬНОГО ПРОЦЕССА В ИНТЕРЕСАХ ЗАЩИТЫ КОНСТИТУЦИОННОГО СТРОЯ
}

Государственная власть не может рассчитывать на длительное существование и эффективную деятельность, полагаясь только на принуждение. Необходимо добровольное согласие большинства законопослушного населения. При этом основной предпосылкой добровольного согласия является уверенность народа в том, что представители власти с полным основанием занимают свои посты, что они вырабатывают и претворяют в жизнь свои решения в сфере законных жизненно важных интересов общества. Там, где легитимность власти не бесспорна, воцаряется беззаконие и опасность революционных потрясений ${ }^{1}$.

Проблема легитимации публичной власти приобрела особое значение в связи с успешным использованием США и их военно-политическими союзниками технологии формирования в стратегических регионах мира зависимых политических режимов с контролируемой системой органов государственной власти. Возможности целенаправленного воздействия на избирательный процесс были продемонстрированы в ходе выборов Президента Югославии 2000 г., Парламента Грузии 2003 г., Президента Украины 2004 г., Парламента Палестинской автономии 2006 г., Президента Республики Беларусь 2006 г., Парламента Республики Беларусь 2008 г, Президента Ирана 2009 г. и др. Американские программы расшатывания конституционного строя и смены политических режимов (Regime Change) 
основаны на актуализации вопроса легитимности власти, что обусловливает необходимость теоретического исследования процесса и моделей легитимации представительной власти в интересах защиты конституционного строя.

Признание власти легитимной осуществляется в результате ее легитимации. Сущность легитимации власти выражается в контроле, осуществляемом определенными социальными группами, деятельности государственного аппарата.

Процесс легитимации публичной власти можно структурно представить в виде легитимации избирательного процесса и легитимации назначения должностных лиц различного уровня. Легитимация избирательного процесса включает в себя законность прохождения выборов, а также принятие общественностью внутри страны и (или) за ее пределами сформированной в условиях избирательной кампании политической власти, готовность выполнять ее требования. Легитимация назначения должностных лиц предполагает авторитет кандидатуры, eе поддержку большинством и желание подчиненных следовать указаниям назначенного лица.

Как представляется, легитимация избирательного процесса имеет два аспекта: внутренний и внешний. Внутренний аспект означает признание населением государства результатов выборов представительных органов власти. Внутренний аспект легитимации неразрывно связан с политической активностью, развитым правосознанием избирателей, демократичностью законодательства о выборах, законностью избирательных действий и процедур, популярностью кандидатов в депутаты или на выборные должности, авторитетом избирательных комиссий в глазах общества, свободой массовой информации, независимостью политических партий и кандидатов от государственных и муниципальных органов. Внутренняя легитимация избирательного процесса является главным условием политической стабильности и незыблемости конституционного строя. Готовность граждан поддерживать и выполнять требования 
представительной власти определяет ее жизнеспособность и эффективность реализации проводимого избранными должностными лицами политического курса. Правящие политические силы заинтересованы в удержании государственной власти с помощью завоевания и сохранения доверия населения. В связи с этим внутренний аспект легитимации избирательного процесса имеет определяющее значение для защиты конституционного строя.

Внешний аспект легитимации избирательного процесса обусловлен признанием результатов выборов иностранными (международными) мониторинговыми миссиями, а также поддержкой сформированной в условиях избирательной кампании политической власти со стороны уполномоченных государственных органов иностранных государств. Внешняя легитимация избирательного процесса может зависеть не только от политической активности населения, законности избирательных действий и процедур, но и от политической ориентации основных претендентов на выборные должности, сложившихся отношений руководства страны с США, Евросоюзом, ключевыми военно-политическими блоками, экономической роли государства в мировой и региональной экономике. Внешняя легитимация избирательного процесса в ряде случаев осуществляется под условием допуска иностранных инвесторов в стратегические национальные отрасли экономики, заключения выгодных соглашений в топливноэнергетической и сырьевой областях, представления межгосударственных займов, размещения иностранных военных баз на территории наблюдаемого государства.

Внешняя легитимация избирательного процесса, подменяющая волеизъявление граждан, подрывает народный и государственный суверенитет. Политическая власть, опирающаяся главным образом на внешнюю поддержку, не имеет долгосрочных перспектив и устойчивости. Органы публичной власти, образованные в ходе «управляемых» избирательных кампаний при вмешательстве иностранных государств и 
международных организаций, выражают, в первую очередь, интересы метрополий, марионетками которых они и являются.

Исходя из наличия двух аспектов легитимации избирательного процесса, соответствующих субъектов и условий легитимации возможны 4 основные модели легитимации представительной власти:

1) избранные органы власти внутренне и внешне легитимны;

2) избранные органы власти внутренне легитимны, внешне нелигитимны;

3) избранные органы власти внутренне нелигитимны, внешне легитимны;

4) избранные органы власти внутренне и внешне нелигитимны.

Наиболее стабильной и долговременной является политическая система, в рамках которой избранные органы власти внутренне и внешне легитимны (признаны внутренним и внешним субъектами легитимации). Наименее стабильной и кратковременной по продолжительности существования политическая система, в которой отсутствуют внутренняя и внешняя легитимность.

В качестве примера можно рассмотреть парламентские выборы в Таиланде, состоявшиеся в декабре 2007 г. Иностранные (международные) и национальные мониторинговые миссии не признали результаты выборов в связи с массовыми фальсификациями. Регулярные демонстрации протеста многочисленных противников победившей на выборах «Партии народной власти», решение Конституционного суда Таиланда о роспуске правящей партии в связи с фальсификацией результатов выборов привели к смене руководства страны и трансформации политической системы.

Две смешанные модели легитимации представительной власти характеризуются наличием только одного (внутреннего или внешнего) субъекта легитимации. Устойчивость политических систем, основанных на смешанных моделях легитимации власти, зависит от ряда условий: уровня жизни, традиций, психологии, правосознания населения; 
коррумпированности государственного аппарата и органов местного самоуправления; расстановки политических сил внутри страны; наличия военно-политических союзников регионального и глобального масштаба; объемов финансовой поддержки политического режима внутри страны и за ее пределами.

Примером смешанной модели легитимации представительной власти, в рамках которой избранные органы власти внутренне легитимны, а внешне нелигитимны, может служить Австрия после успешного участия в парламентских выборах 2000 г. националистической политической партии «Свобода». Формирование коалиции с участием партии «Свобода» повлекло за собой санкции 14 государств ЕС (прекращение официальных контактов с Правительством Австрии, технический уровень контактов с послами Австрии, бойкот австрийских кандидатов на должности в международных организациях).

Аналогичная модель легитимации представительной складывалась в течение длительного времени в Республике Беларусь. Соединенные Штаты Америки, Евросоюз, Совет Европы, Европарламент и ОБСЕ регулярно не признавали результаты национальных выборов в Республике Беларусь (выборов Президента 2001 и 2006 гг., выборов членов Совета Республики и депутатов Палаты представителей Национального Собрания Республики Беларусь 2000, 2004 и 2008 гг.) и применяли ограничительные меры политического и экономического характера в отношении Республики Беларусь.

Модель легитимации представительной власти, основанная на внешней легитимности, была сформирована в Афганистане в результате президентских выборов 2004 и 2009 гг., парламентских выборов 2005 г.

Характерными являются выборы Президента Афганистана 2009 г., сопровождавшиеся массовыми фальсификациями избирательных документов и результатов выборов. Прошедшие выборы не являлись свободными, справедливыми и прозрачными. Около 30\% избирательных участков не 
функционировали в связи с угрозами обеспечения безопасности избирателей, ракетными обстрелами, взрывами и террористическими атаками боевиков движения «Талибан». В северных и восточных провинциях явка избирателей была критически низкой. Итоги голосования были официально аннулированы на 447 избирательных участках (в первую очередь, в провинциях Пантика, Кандагар, Газни). 15 из 18 кандидатов в Президенты Республики Афганистан заявили о существенном искажении народного волеизъявления и своем отказе признать результаты состоявшихся выборов. 1 ноября 2009 г. основной соперник действующего президента Хамида Карзая Абдулла Абдулла отказался от участия во втором туре президентских выборов, мотивировав свое решение тем, что условия для справедливых и прозрачных выборов в Афганистане не созданы.

Тем не менее, учитывая слабые экономические и военно-политические возможности правительства Афганистана, последовательную реализацию афганской политики в рамках внешнеполитической стратегии США, необходимость нормализации обстановки в стране, примирения наркоторговцев, боевиков Талибана, полевых командиров радикальных группировок и политических функционеров - ставленников оккупационного режима, потребности усиления политического влияния Хамида Карзая, вопрос внешнего признания результатов выборов и легитимации существующей власти в Афганистане носит для руководства США и Евросоюза принципиальный характер. Поэтому любые выборы, состоявшиеся в Афганистане, и их результаты будут признаны и поддержаны Администрацией Соединенных Штатов и их союзниками.

Следует различать понятия «легитимность» и «легальность» публичной власти ${ }^{2}$. Понятие легитимности носит оценочный и политический характер, легальность же предполагает формально-юридическую характеристику публичной власти. Государственная власть, даже не популярная, как правило, является легальной. В то же время она может быть нелегитимной, то есть не приниматься народом, несмотря на свое монопольное право 
издавать законы и использовать их как орудие организованного принуждения. Легитимность публичной власти означает социальное признание ее права на руководящую роль в обществе ${ }^{3}$.

Основой легитимности политической власти служит добровольное подчинение законам, рассмотрение власти как авторитетной для индивида инстанции. Легитимность власти нарушается, если она неспособна подчиняться, следовать своим собственным нормам. Поэтому легальность публичной власти, выражающаяся в еe способности оперировать и руководствоваться законами, служит базой легитимности власти ${ }^{4}$.

Легитимность - это не только законность данной власти с формальноюридической точки зрения, но и явление социально-психологическое, состоящее в принятии обществом данной политической власти или, как минимум, пассивном повиновении ей5 ${ }^{5}$ По мнению А.И. Демидова, смысл легитимности политической власти заключается в принятии ее теми людьми, на которые она распространяется, в признании ими ее права управлять и в их согласии подчиняться ${ }^{6}$ Так, вновь возникающие политические режимы (вследствие революций, военных переворотов и т.п.) могут стать легитимными, если обеспечат себе поддержку значительной части общества.

В связи с тематикой защиты конституционного строя представляется целесообразным выделить проблему легитимации власти, полученной незаконным путем, и проблему делегитимации власти, полученной конституционным путем.

Легитимация власти, полученной неконституционным путем, происходит при наличии следующих условий: пассивности населения или готовности граждан к сотрудничеству с органами власти; решения судебного органа о признании результатов выборов; поддержки избранных органов власти международными организациями и официальными представителями зарубежных стран; возможности блокирования массовой информации, содержащей юридическую оценку осуществленного захвата власти как противоправного деяния. 
Делегитимация власти, полученной конституционным путем, определяется: кризисным состоянием экономики государства и низким жизненным уровнем населения; несправедливым распределением общественных благ; антисоциальной политикой и непопулярными реформистскими мерами правящих политических партий и выборных должностных лиц; готовностью населения отстаивать свои права и свободы; ненадлежащим исполнением или неисполнением распоряжений и нормативных правовых актов избранных органов власти; национальной и зарубежной пропагандой нелигитимности сформированных на выборах органов власти; девальвацией духовных ценностей и правовым нигилизмом граждан.

Одной из важнейших составляющих легитимности публичной власти является безопасность. Население поддерживает ту политическую систему и организацию власти, в рамках которых оно чувствует себя защищенным. Как справедливо отмечает А.Г. Бедов, легитимная политическая власть упорядочивает общественные отношения, придает «определенность направлениям деятельности властных структур, постоянство нормативов, привычность типов поведения» ${ }^{7}$. Политическая власть, утверждающая в обществе такие качества легитимности, как легальность, безопасность, порядок, приобретает авторитет - люди добровольно передают ей свои властные полномочия, соглашаются подчиняться, чувствуют сопричастность властным действиям и способствуют им. Такая власть становится суверенной, обладающей способностью принимать решения, которые не могут быть пересмотрены никаким иным органом или организацией, кроме принявшего их ${ }^{8}$.

Неспособность публичной власти осуществлять свои полномочия, неэффективность реализации функций государства приводят к постепенному ограничению и утрате суверенитета, подрывают основы конституционного строя. 
Обеспечение легитимации результатов избирательного процесса и оптимизации формирования органов государственной власти является необходимым условием устойчивого прогрессивного развития любого демократического суверенного государства.

В статье анализируются теоретико-правовые аспекты легитимации избирательного процесса в интересах защиты конституционного строя. Автором рассмотрены технологии смены политических режимов в ходе «цветных» революций и раскрыты модели легитимации представительной власти.

Ключевые слова: легитимация избирательного процесса в интересах защиты конституционного строя, фальсификации выборов, обжалование результатов выборов, «цветные» революции, смена политического режима, легитимация политической власти.

The article examines theoretical and legal aspects of political power legitimation in the interests of protection of political system. The author studies the technologies of changing political regimes during «colour revolutions» and investigates the political power legitimation models.

Key words: legitimation of the electoral process in the interests of protection of political system, election falsification, appealing election results, «colour revolutions», regime change, legitimation of political power.

Красинский Владислав Вячеславович кандидат юридических наук, эксперт Российского общественного института избирательного права (РОИИП)

Источник опубликования: Красинский В.В. Теоретико-правовые аспекты легитимации избирательного процесса в интересах защиты конституционного строя // Современное право. 2010. № 3. С. 9-13.

${ }^{1}$ См.: Шаран П. Сравнительная политология. Ч. 1. М., 1992. С. 113-114.

2 Подробней см: Чиркин B.E. Легализация и легитимация государственной власти // Государство и право. 1995. № 8. С. 65-73.

${ }^{3}$ См.: Волков В.П., Дамаскин О.В., Шапиев С.М. Некоторые проблемы и пути их решения для обеспечения законности избирательного процесса в Российской Федерации. М.: РЦОИТ, 2009. С. 162. 
${ }^{4}$ См. Политология для юристов / Под ред. Н.И. Матузова и А.В. Малько. М.: Юристь, 2002. С. 64-65.

${ }^{5}$ См.: Волков В.П., Дамаскин О.В., Шапиев С.М. Указ. соч. С. 162.

${ }^{6}$ См. Политология для юристов / Под ред. Н.И. Матузова и А.В. Малько. М.: Юристъ, 2002. С. 64.

${ }^{7}$ См.: Бедов А.Г. Политология. М., 1994. С. 207.

${ }^{8}$ См. Политология для юристов / Под ред. Н.И. Матузова и А.В. Малько. М.: Юристъ, 2002. С. 70. 